\title{
Sexual Coercion at sexual debut and associated factors among Young Females in rural areas of Boset District, Eastern Ethiopia: A Mixed Method Study
}

Sileshi Garoma Abeya ( $\sim$ garomaabe@gmail.com )

Adama Hospital Medical College

Research article

Keywords: Coercion, sexual debut, rural, Ethiopia

Posted Date: August 28th, 2020

DOI: https://doi.org/10.21203/rs.3.rs-42440/v1

License: (9) This work is licensed under a Creative Commons Attribution 4.0 International License. Read Full License 


\section{Abstract \\ Background}

The sexual behavior and experience of young people in developing countries have considerable attention. Despite growing recognition of the problem, relatively little is known about the issue of coercive sex in rural settings in developing countries including Ethiopia.

\section{Objectives}

Assess the prevalence and associated factors of sexual coercion at sexual debut among young females in rural areas of Boset district, Oromia Region, Eastern Ethiopia.

\section{Methods}

Cross-sectional community based study was conducted using both qualitative and quantitative data collection methods. A sample of 632 young females aged 10-24 years was taken from six rural Kebeles by systematic random sampling procedure for quantitative and data were collected using a pre-tested structured questionnaire. The collected data were analyzed using SPSS version 23. Principally Binary Logistic regression model was fitted. Moreover, eight focus group discussions targeting different groups were held and analyzed thematically.

\section{Results}

The prevalence of sexual coercion at sexual debut was 36.5\% among sexually active respondents. Married young female (COR, 0.39; 95\% Cl: 0.21,0.71), living alone (away from their parents (AOR, 5.07; 95\%Cl: 1.07,24.01), age (AOR, 0.19; 95\%Cl: 0. 064, 0.544), alcohol consumption (AOR, 2.44; 95\%Cl: 1.17, 5.08 ) and Khat chewing (AOR, $8.30 ; 95 \% \mathrm{Cl}: 1.892,36.378)$ were factors predicting the likelihood of having sexual coercion at sexual debut.

\section{Conclusion}

Sexual coercion at sexual debut is a major public health problem among young females in the study community. The emerging program interventions need to take this problem into consideration.

\section{Background}

Sexual coercion is the act of being physically, psychologically, financially or otherwise forced or tricked into engaging in sexual activity $[1,2]$. Most commonly the victims of sexual coercion are women and 
children $[3,4]$. These includes acts of being worn down by someone who repeatedly asks for sex being lied to or being promised things that weren't true to trick you into having sex; having someone threaten to end a relationship or spread rumors about you if you don't have sex with them; and having an authority figure, like a boss, property manager use their influence or authority to pressure young female into having sex $[5,6]$. It is commonly believed that sexual coercion is perpetrated by the male sex against the female sex [5]. For example, in a community based study $33 \%$ of young peoples reported having sexual coercion and $70 \%$ of them new their perpetrator (a boyfriend and an acquaintance)[2].

Studies in the fields of sexual coercion at sexual debut, including rape are usually based on biased estimates to elicit the relationship between the victims and rapist characterization of the prevalence is challenging [2, 7]. There are also popular myths among both victims and perpetrators [8]. Some of the commonly perceived myths are sexual coercion is performed by strangers in dangerous places; the offender or perpetrators are deviates or distorts, and they are more likely to socially and psychologically normal acquaintances $[2,8]$.

Modifiable predictors of sexual coercion at sexual debut are poorly understood, particularly among young people in rural areas who may have less access to sexual health resources $[6,7,9]$. Study examined sexual coercion at sexual debut among rural young females in low-to-middle income counties found $23 \%$ on average $[10,11]$. In the context of sexual coercion drugs/alcohol consumption by both men and women is one of the most frequently cited to lower the victims inhibition (loosen them up) or lesson their verbal resistance of sexual advances. Ages, parental communication, marital status, education, living arrangements are among many factors frequently associated with sexual coercion at sexual debut [4, 12-14].

However, there is a paucity of information on the prevalence and associated factors estimates of sexual coercion at sexual debut among young people in urban and university settings of Ethiopia [12,15-18]. However, in rural Ethiopia, where more than $80 \%$ of the young people live, the prevalence and associated factors of sexual coercion at sexual debut is not well explored. Obtaining reliable estimates of sexual coercion among rural adolescents is important given the challenging social norms and myths. This study assessed the prevalence of sexual coercion at sexual debut and associated factors in the rural settings of Ethiopia during 2019.

\section{Methods}

\section{Study Area}

The study was conducted in rural Kebeles (the lowest administrative unit in government structure) among young females (10-24 years) in Boset district, Eastern Ethiopia. The district is found in East Shoa Zone of Oromia Region 120 kilometers away from Addis Ababa. The district has a total population of 497, 143 during in 2019/20 projected from 2007 Census conducted by the Central Statistical Agency of Ethiopia, considering $2.9 \%$ as rate of natural increase [19]. The total number of those aged $10-24$ years in the 
district was estimated to be 154,114 based on the assumption of $31 \%$ of all segment of the population [20].

\section{Study Design and Period}

A community based cross-sectional design was employed using both quantitative and qualitative data collection methods from May to June, 2019.

\section{Population}

All young females (10-24 years) and those living in randomly selected households of rural Kebeles in Boset district were the source and study population, respectively. Those young females who have lived at least for six months in the district prior to the survey were included, while those critically ill, mentally deficient and unable to respond to the questionnaire were excluded from the study.

\section{Sample Size}

The required sample size was calculated by a single population proportion formula using 50\% proportion of sexual coercion among young females of in the absence the absence of information from rural settings, at $95 \%$ confidence level, precision of 5\%, design effect of 1.5 and adding 15 percent for the possible non responses due to the sensitive nature of the study. Finally, a minimum of 662 study subjects was needed for the study.

\section{Sampling Procedure}

Multistage sampling method was used to randomly select six from 40 rural Kebeles in the Boset district. To identify eligible, the household census and numbering was carried out prior to data collection. Based on the identified households having the target group, the probability proportional to sample size allocation was carried out. Finally, systematic random sampling was used to include the eligible into the study. Indeed, only one was selected by lottery method if the household has two or more eligible to control for potential intra household correlation.

\section{Data Collection}

Quantitative data were collected using structured interviewer administered questionnaire developed after reviewing relevant literatures. The questionnaire was translated into the regional working language ( $A f a n$ Oromo) and translated back to English by experts (Supplementary File 1). Pretest of the questionnaire was carried out on similar setting on young females who had similar socio-demographic characteristics by considering $5 \%$ of the total sample size. The data were collected by 10 th grade completed young females and supervised by Public Health officers. An interviewer paid a maximum of three visits to the selected households to locate respondents and in case of absenteeism eligible in the adjacent households has been interviewed. To ensure the validity of the data, $10 \%$ of the questionnaires were randomly checked for completeness by supervisors and principal investigator. A total of Eight FGDs was held from young people, elderly and religious leaders and governmental employees. Discussions were 
facilitated using a discussion guide prepared according to the theme of the study. The discussions were audio recorded for later transcribed verbatim.

\section{Data Analysis}

The collected data were cleaned, coded and entered into Epilnfo Version 3.1 and exported to SPSS 23 for analysis. Descriptive statistics were used to determine the proportion of sexual coercion among the study participants. The associations between the study variables were computed using binary logistic regression analysis. In the final model, variables having a $P$ value of $<0.25$ at bivariable level were chosen and entered into the model using the forward selection method to estimate the adjusted effects of the predictor variables. The odds Ratio with $95 \%$ confidence intervals were calculated to indicate the strengths of the associations between the study variables. The significance of the association was declared at $p$-value of 0.05 . The multicolliniarity between the independent variables using Variance Inflation Factor (VIF) and goodness of fit using Hosmer and Lemishow test were checked to be satisfied. The model's ability to correctly classify the outcome was assessed using Receiver Operating Characteristic curve (ROC). For the qualitative information verbatim transcriptions were used. Texts were imported to Open Code 2007 program to facilitate the coding process [21]. Relevant cods were arranged into categories to arrive at predetermined themes. The trustworthiness of qualitative information was ensured by recruiting appropriate discussants and member checking was also used after write up of the texts. The results of qualitative information were used to complement the quantitative results and discussions.

\section{Operational Definitions}

Young people: are those who are in the age group of 10 to 19 years.

Sexual coercion: Unwanted or unwillingly completed penetration because of one or more of the followings: deception (promise) or reward, the threat of non-physical punishment or verbal pressure, exchange of sex for money/ gifts/favor (transactional sex), by the use of physical force/rape and use of substances (alcohol, chat and drugs).

Sexual debut: Those young females experienced penetrative sexual intercourse for the first time.

\section{Results}

\section{Socio-demographic and behavioral Characteristics}

It was planned to include 662 young females to the study and 632 were participated, making a response rate of $95 \%$. One hundred twenty four (19.6\%) were in the age range of 10-14 years. The mean ( \pm SD) age of the respondents was $17.2( \pm 3.3)$ years. Most $(83.7 \%)$ were not married (single), while $13.8 \%$ were ever married. About seven in ten (70.4) of them were students and $4 \%$ of them were never attended education and considered to be illiterate during the data collection time. More than four in ten (41.9\%) currently 
living with their parents, while $5.1 \%$ were living alone. About one of seven (14.7\%) of the participants used alcoholic beverage and $2.7 \%$ chewed Khat (Table 1).

Insert Table 1 here

\section{Prevalence of Sexual Coercion at Sexual debut}

The proportion of young female ever experienced penetrative sexual intercourse was 233 (36.9\%). The mean $( \pm S D)$ age at first sexual commencement was $16.64( \pm 1.97)$ years. The majority, $191(81.8 \%)$ started to have sexual intercourse between the ages of 15-19 years, while $27(11.7 \%)$ started between 10 14 years and only 15 (6.5\%) were started between $20-24$ years to have their first sex. From the reasons on sexual commencement for the first time, 85 (36.5\%) mentioned due to sexual coercion, while because of marriage, falling in love and personal desire accounted for 59 (25.3\%), 74 (31.7) and 15 (6.6\%), respectively (Figure 1 ).

Insert Figure 1 here

Regarding the types of sexual coercion at sexual debut, the victims faced multiple forms at the same time. More than a quarter (27.6\%) were physically forced/raped, while nearly one in five (21.3) deceived or misled by promising words and the rest $13.7 \%, 9.3 \%, 4 \%$ and $0.9 \%$ of the victims started their first sexual intercourse by verbal threats, exchange for gifts/ property, by making them drunk or after chewing Khat and watching pornographic movies/pictures, respectively (Figure 2).

Insert Figure 2 here

The result is substantiated by the results of FGD explored usually the sexual intercourse with girls is being practiced at the study area on the basis of economic support, physical forces/rape, and deception or misleading words coming from men for deflowering by repeatedly saying, "I love you very much".

One of the discussant said "Qalbiin debate amma ija xaafii geese, isseeyyuu yoo dhungatani lafa keessil" meaning the discerning range of mind of females towards sexuality is as small as a seed of "millet", which even she can lose it if kissed (38 years married women). This implies that females are easily flattered over sexual desire.

The discussants also mentioned pressure from peers is not uncommon. Men can make an agreement with their intimate friend of female that makes a mediating task in persuading another female (girls) for her friend so as to adjoin the unintended female with the man behind the trap is another system of sexual offenses or fornications in the area.

They further mentioned threatening girl friends to have sexual intercourse is another problem of sexual offense by saying, "I will find another girl, if you didn't allow me",though she tries to convince him to wait 
until she completes her schooling. In line with this, men try to provoke girl friends to make sex by saying "let me check whether you are virgin or not".

Literally they are using the local language "Anoo durbummaakee hinballeessu nan borrosha malee" meaning "I don't deflower you, but to check it." (31 years male governmental employee)

In the same notion, the perpetrators used physical force to have sexual intercourse with young females. This was complemented by the results from FGDs and one young woman described the fact that:

"Culturally, females are forced into sexual intercourse "Dubartiif harreen ulee jaallattii jechudhaan dubartii reebanii gudeedu". (23 years married women). Meaning, men make sexual intercourse with females by beating them even if they refuse, saying "...females and donkey like beating by stick'.

Other discussants from religious organizations recounting her first sexual experience with her boyfriend at age 15 said:

"It was a terrifying experience; when I tried to resist, he pinned my arms above my head. It must have been so painful and suffocating that I fainted". (38 year married woman) (Supplementary File 2)

Moreover, most discussants mentioned, making females drink alcoholic beverages and Khat chewing for arousing her sexual feeling is a common mechanism for males to initiate females. According to this belief, forcing females into sexual intercourse after taking alcohol is a common practice by men even within a marital union.

The study showed for the relationship of perpetrators to victims, from the victims $23.8 \%, 27.7 \%$ and $18.8 \%$ were victimized by acquaintance, boyfriends and by their fiancées, respectively, whereas stranger victimized only $8.9 \%$. According to the results from FGDs participants revealed the fact that some authority personnel's are also the perpetrators of sexual coercion by deceiving young females for employing into government work in exchange of sex. Other discussants claimed, teachers are also intimidating young females for passing examinations as well as giving favors and property, while some said; elderly people, married men, health professionals, acquaintance, passengers (casual), relatives, rich persons (business men), relatives, unemployed, drivers, gangs, etc. are the committers of sexual coercion. In addition, some of them mentioned, film watchers and alcohol initiated individuals are continually forcing females in to having sexual intercourse.

The estimated age of perpetrators during the time of sexual coercion was further asked and for one fourth $(25.7 \%)$ of them it was about $1-4$ years older than the victims, while $21.8 \%$ were $5-10$ years older. Similarly, $71.3 \%$ of the perpetrators were single or never married and $13.9 \%$ were ever married when they were committed a sexual coercion the young females. For those who coerced at sexual debut, most (33.7\%) of the events were occurring in the offender's house and dating place, including the in the bush. In doing so, $10.9 \%$ of the victims of sexual coercion have reported the events to legal bodies, their families and friends. Among those reasons mentioned for not reporting, fear of consequences from the act (58.9\%), fear of social stigma from the community (46.7\%), cultural influences (30\%) and the threat of 
harm by the offender (41.1\%) were mentioned. Moreover, few $(16.8 \%)$ of all cases sought health institutions for help (Table 2).

Insert Table 2 here

\section{Factors associated with Sexual Coercion at sexual debut}

Those married young females and living with their spouse reported less likelihood of sexual coercion at sexual debut compared to never married young females (COR, $0.39 ; 95 \% \mathrm{Cl}: 0.21,0.71$ ). But, it was no more significant after being adjusted all other factors. On the other hand, considering young females living with their parents, those living alone had significantly increased likelihood of having sexual coercion at sexual debut (AOR, 5.07; 95\% Cl: 1.07,24.01). Also, age at first sexual commencement of young females was found to be a significant predictor, with young female 15-19years were significantly less likely to report having experienced sexual coercion at sexual debut compared to 10-14 years (AOR, $0.19 ; 95 \% \mathrm{Cl}: 0.064,0.544)$. Ever consuming alcoholic beverages by young females was significantly associated with sexual coercion at sexual debut (AOR, 2.44; $95 \% \mathrm{Cl}: 1.17,5.08)$. Similarly, those young females who had ever chewed khat had a significantly higher likelihood of having sexual coercion at sexual debut (AOR, 8.30; 95\%Cl: 1.892, 36.378) (Table 3).

Insert Table 3 here

\section{Discussions}

This study used a community based cross-sectional design using a mixed method of data collection method and highlighted the prevalence of sexual coercion at sexual debut and associated factors among young females in rural Ethiopia.

From the sexually experienced young females the reported reasons for sexual commencement, sexual coercion is the highest and constituted $36.5 \%$. This finding is consistent with the reports from different studies around the African countries indicated the prevalence of nonconsensual first sexual experiences among young female of $33.1 \%$ in Uganda [22] and $27.5 \%$ in Nigeria [23]. Similar reports were shown in a study among young females in University and College students of Ethiopia that showed $43.3 \%$ in Bishoftu town [24], and $45.4 \%$ in Wolayita Sodo [25]. The variation in prevalence is attributed to the differences in the study settings in which the majority of the studies were conducted in school and urban settings. The majority of FGD discussants approved for these reasons as a cause of sexual debut for young females and further mentioned the issues considering as a serious problem of the study area.

In this study, the greater proportion (23.4\%) of sexually coerced young females at sexual debut reported sex by the use of physical force/rape. This is more than $12.7 \%$ in in Addis Ababa [26] and $20.8 \%$ from Nekemte town [27]. These might be due to urban rural disparities as rape is more common in rural communities of Ethiopia as cultural acceptance is evidenced from the results of FGDs. For a significant 
proportion of the victims, boyfriends $(27.7 \%)$ and acquaintances $(23.8 \%)$ were the perpetrators of sexual coercion at sexual debut and a smaller proportion (8.9\%) were coerced by an unknown person to the victim (strangers). It is comparable with similar reports from Kenya, which indicated that acquaintances and strangers perpetrated $21.8 \%$ and $8.2 \%$ of sexual coercions at sexual debut, respectively [28]. With regard to the age of the perpetrators, only $16.8 \%$ of the victims were reported about the same age, while the majority reported for the age of the perpetrators was more than the victim's age, even $5.9 \%$ of them were reported to about 10 years and above differences. This shows that some young female experience non-consensual sexual relationships with older, more powerful partners with whom they may feel unable to negotiate and perform unsafe sexual practices.

Married young women were less likely than single to report sexual coercion at sexual debut. This is different from similar studies in Kenya, which showed young females who had ever been married, and those who did not live with their parents had a significantly elevated risk of sexual coercion at sexual debut [28]. This is corroborating the notion that marriage is a safe refuge especially for the young females. Young females living alone were significantly at higher risk of getting sexual coercion al debut than those living with their parents. Similar findings were reported in other similar studies $[14,25,27]$. This was complemented by most discussants from FGDs mentioning for the young females living away from parents are more vulnerable to sexual coercion. The study also showed a significant association between earlier onset of sexual relations among young females and greater risk of sexual coercion. This is supported by the reports from studies conducted elsewhere, explaining for being earlier age is vulnerable to unwanted sexual intercourse and young female who initiated sex at very young ages may also have experienced some sort of pressure either physical or verbal to have sex against their will $[4,6$, $22,28]$.

This study highlights the prominent role of drinking alcoholic beverages and chewing khat by young female increasing the risk of sexual coercion at sexual debut. These are evidenced by various studies on the subject area $[4,16,24,27]$. The plausible explanation for these might be behavioral risk factors that put young females at increased vulnerability to sexual coercion, because they might not control themselves over sexual feelings by interpreting and effectively acting on warning signs. All FGDs group briefly mentioned the role of alcohol and Khat use in association with sexual coercion for the young female in the study area.

As to the limitation of this study, due to the cores sectional nature it might not be possible to ascertain the direction of the cause effect relationships between the study variables. Also, social desirability bias was inevitable due to the sensitive nature of the study. Despite these limitations it is possible to generalize the findings of this study to similar rural settings having similar socio-demographic characteristics in the country.

\section{Conclusion}


Sexual coercion at sexual debut constitutes the largest proportion among other reasons for sexual commencement. Sexual experiences using physical force, Rape by the perpetrator constitutes the highest proportion from the defined forms of sexual coercion at sexual debut. The perpetrators of sexual coercion at sexual debut were mostly boyfriends and acquaintances.

Those unmarried young females and living alone (away from their parents) were at increased likelihood of sexual coercion at sexual debut. Similarly, young female who started sexual intercourse earlier, and drinking alcoholic beverages as well as chewing khat were significantly at increased risk of having sexual coercion at sexual debut. The emerging program interventions need to take into consideration in order to address the full context of young female lives, including the societal and behavioral factors leading to these problems. Moreover, there is a need to improve the communication skill and assertiveness through life skill training for young females in rural areas.

\section{Abbreviations}

AOR

Adjusted Odds Ratio

COR

Crude Odds Ratio

IRB

Institutional Review Board

SD

Standard Deviation

\section{Declarations}

\section{Ethics approval and consent to participate}

As part of the staff research, the ethical clearance was received from an Ethical Committee and Institutional Review Board (IRB) of the Adama Hospital Medical College. Official letter was issued to the concerned bodies by the department of Population Health. Written consents from the participants and or parents of the study participant's age less than 16 years were secured. Before undertaking the interview and discussions, participants were informed to have a full right to agree or disagree and or withdraw any time. All interviews and discussions took place at complete privacy and comfortable places.

\section{Consent to publication}

Not Applicable

\section{Authors' contribution}


SG initiated and conducted the study. Analysis, write up and drafting of the manuscript is also done by SG.

\section{Funding}

No funding was obtained for this study

\section{Competing Interest}

The author confirms as there is no conflict of Interest.

\section{Availability of data and materials}

All data generated or analysed during this study are included

\section{Acknowledgements}

I acknowledge the Adama Hospital Medical College for funding the study. My sincere thanks also go to the data collectors, supervisors and study participants for their willingness to participate in the study.

\section{References}

1. Smith SG, Zhang X, Basile KC, Merrick MT, Wang J, Kresnow M., Chen J. The National Intimate Partner and Sexual Violence Survey (NISVS): Data Brief - Updated Release. Atlanta, GA: National Center for Injury Prevention and Control, Centers for Disease Control and Prevention. Available at: https://www.cdc.gov/violenceprevention/pdf/2015data-brief508.pdf. 2015.

2. Violence against women. Relevance for Medical Practioners. Council on scientific affairs. American Medical Association. JAMA. 1992;267:3184-9.

3. Sarkar J, Mental health assessment of rape offenders. Indian J Psychiatry, 2013(55): p. 235-43.

4. Amy J. Katz, Devon J. Hensel, Abby L. Hunt, Leigh S. Zaban, Monique M. Hensley and Mary A. Ott, Only Yes Means Yes: Sexual Coercion in Rural Adolescent Relationships. Journal of Adolescent 2019(04): p. 1016.

5. Sathyanarayana Rao T S and Andrade C, Childhood sexual abuse and the law: More problems than solutions? . Indian J Psychiatry, 2013(55): p. 214-5.

6. Lee RLT, Yuen Loke A, Hung TTM, Sobel H. A systematic review on identifying risk factors associated with early sexual debut and coerced sex among adolescents and young people in communities.J Clin Nurs., 2018 27(3-4): p. 478-501.

7. Rominski SD, Moyer CA, and E. KM., Sexual Coercion Among Students at the University of Cape Coast, Ghana Sexuality \& Culture, 2017. 21: p. 516-533.

8. Manzer D, O'Sullivan, LF. Doucet SMyths, misunderstandings, and missing information: Experiences of nurse practitioners in delivery primary care to lesbian, gay, bisexual and transgender (LGBT) patients.Canadian Journal of Human Sexuality, 2018(27): p. 157-170. 
9. Girmay A, Mariye T, and Gerensea H. Early sexual debut and associated factors among secondary school students of central zone of Tigray, Northern Ethiopia. Pan African Medical Journal, 2019(34:1).

10. Pediatric Academic Societies. Factors associated with sexual coercion among adolescents in rural communities. Available at: https://medicalxpress.com/news/2018-05-factors-sexual-coercionadolescents-rural.html.

11. HuipingZhang, YiZhang, SusanFan, Paul Siu FaiYip. Sexual coercion among Hong Kong Chinese adolescents: The role of family factors. Available at: https://doi.org/10.1016/j.childyouth.2019.03.034.

12. Bekele T and Deressa W, Experience of Sexual Coercion and Associated Factors among Female Students of Ambo University in Ethiopia.Science Journal of Public Health, 2014. 2: p. 532-538.

13. Kassahun EA, Gelagay AA, Muche AA, Dessie AA, Kassie BA. Factors associated with early sexual initiation among preparatory and high school youths in Woldia town, northeast Ethiopia: a crosssectional study. BMC Public Health, 2019. 19:378.

14. Girmay A and M. T. Risky sexual behavior practice and associated factors among secondary and preparatory school students of Aksum town, northern Ethiopia.BMC Res Notes, 2019(12): p. 698.

15. Kassa S, Molla A, and Cherie N, Sexual Coercion and Determinant Factors among Female Students in Wollo University, Ethiopia. Kenkyu Journal of Epidemiology \& Community Medicine, 2019. 5: : p. 0113.

16. Takele A and Setegn T, Sexual Coercion and Associated Factors among Female Students of Madawalabu University, Southeast Ethiopia. Advances in Public Health, 2014(8).

17. Adinew YM and Hagos MA, Sexual violence against female university students in Ethiopia. BMC International Health and Human Rights 2017. 17(:19).

18. Seyoum YK, Kediro A, Shiferaw BZ, Fite RO. Sexual Coercion and Associated Factors among Female Private University Students in Bishoftu Town, East Shewa Ethiopia. Journal of Women's Health, Issues \& Care, 2017(6): p. 4.

19. CSA: Statistical Abstract of Federal Democratic Republic of Ethiopia. CSA Addis Ababa, Ethiopia; 2019.

20. Statistical Abstract of Federal Democratic Republic of Ethiopia, CSA, 2019, Addis Ababa, Ethiopia.

21. Open Code 3.4. program: UMDAC and Division of Epidemiology and Public Health Sciences, Department of Public Health and Clinical medicine.: Umea University; 2007.

22. Agardh A, Pettersson KO, and Ö. PO., Experience of sexual coercion and risky sexual behavior among Ugandan university students. BMC Public Health 2011(11): p. 527.

23. SAMUEL BO, SANUSI RA. SEXUAL BEHAVIOURS AND EXPERIENCE OF SEXUAL COERCION AMONG INSCHOOL FEMALE ADOLESCENT IN SOUTHWESTERN NIGERIA. 2019. doi: https://doi.org/10.1101/19000851. 
24. Agardh A, Pettersson KO, Östergren PO. Experience of sexual coercion and risky sexual behavior among Ugandan university students. BMC Public Health 2011, 11:527. Available at: http://www.biomedcentral.com/1471-2458/11/527

25. Adinew YM and Hagos MA, Sexual violence against female university students in Ethiopia. BMC International Health and Human Rights, 2017. 17:19.

26. Tadesse S, Assessment of Sexual Coercion Among Addis Ababa University Female Students. Addis Ababa University Medical Facultydepartment Of Community Health. 2014.

27. Benti T and Teferi E, Sexual Coercion and Associated Factors among College Female Students. J Women's Health Care. 2015(4: 245).

28. Erulkar AS, The Experience of Sexual Coercion Among Young People in Kenya. International Family Planning Perspectives. 30, 2004. 4(182-189).

\section{Tables}

Table 1: Socio-demographic and behavioral Characteristics of the study participants, Boset district, June 2019. 


\begin{tabular}{|c|c|c|c|c|}
\hline Variables & Responses category & & Number & Percent \\
\hline \multirow{3}{*}{$\begin{array}{l}\text { Age in } \\
\text { years }\end{array}$} & $10-14$ & & 124 & 19.6 \\
\hline & $15-19$ & & 332 & 52.5 \\
\hline & $20-24$ & & 176 & 27.9 \\
\hline \multirow{3}{*}{$\begin{array}{l}\text { Marital } \\
\text { status }\end{array}$} & Unmarried & & 530 & 83.7 \\
\hline & Married & & 87 & 13.8 \\
\hline & Others* & & 15 & 2.5 \\
\hline \multirow{6}{*}{$\begin{array}{l}\text { Current } \\
\text { occupation }\end{array}$} & Students & & 470 & 74.4 \\
\hline & Housewife & & 66 & 10.4 \\
\hline & Trade activity & & 21 & 3.3 \\
\hline & Gov. employee & & 6 & 0.9 \\
\hline & Housemaid & & 42 & 6.6 \\
\hline & Others $* \star \star$ & & 27 & 4.4 \\
\hline \multirow[t]{6}{*}{ Grade level } & Illiterate & & 28 & 4.4 \\
\hline & Read and write & & 8 & 1.4 \\
\hline & Primary (1-8) & & 277 & 43.8 \\
\hline & Secondary $(9-10)$ & & 232 & 36.7 \\
\hline & Preparatory (11-12) & & 64 & 10.2 \\
\hline & Collage and above & & 22 & 3.5 \\
\hline \multirow{8}{*}{$\begin{array}{l}\text { Currently } \\
\text { living with }\end{array}$} & Father and Mother & & 265 & 41.9 \\
\hline & $\begin{array}{l}\text { Father only/ Mother } \\
\text { only }\end{array}$ & & 136 & 21.5 \\
\hline & Relatives & Snouco & 92 & 14.6 \\
\hline & मान & 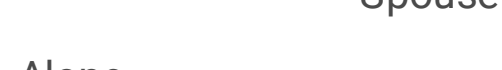 & 9 & 1.4 \\
\hline & $\begin{array}{l}\text { Friends } \\
\text { Maidservant }\end{array}$ & Alone & 66 & 10.4 \\
\hline & & & 6 & 1.0 \\
\hline & & & 32 & 5.1 \\
\hline & & & 26 & 4.1 \\
\hline \multirow{3}{*}{$\begin{array}{l}\text { Consume } \\
\text { Alcoholic } \\
\text { beverage }\end{array}$} & Yes & & \multirow{2}{*}{93} & 14.7 \\
\hline & No & & & 85.3 \\
\hline & & & 539 & \\
\hline
\end{tabular}


A. Others include: *Divorced, widowed and separated, ${ }^{* * E m p l o y e d ~ i n ~ p r i v a t e ~ b u s i n e s s, ~ h a d ~ n o ~ w o r k ~}$ Table 2: Characteristics of perpetrators of sexual coercion at sexual debut among sexually active respondents, Boset district, Oromia Region, June 2019 


\begin{tabular}{|c|c|c|c|}
\hline Variables & Response category & Frequency & Percent \\
\hline \multirow[t]{8}{*}{ Relation of perpetrators to victims $(n=85)$} & An acquaintance & 20 & 23.8 \\
\hline & A friend & 24 & 27.7 \\
\hline & Fiancé & 16 & 18.8 \\
\hline & Spouse & 7 & 7.9 \\
\hline & A relative & 3 & 4.0 \\
\hline & Teachers & 7 & 7.9 \\
\hline & Authority figures & 1 & 1.0 \\
\hline & Strangers & 8 & 8.9 \\
\hline \multirow[t]{7}{*}{ Estimated age of perpetrators $(n=85)$} & About her age & 14 & 16.8 \\
\hline & Younger than her & 16 & 18.8 \\
\hline & $\begin{array}{l}\text { About } 1 \text { to } 4 \text { years } \\
\text { older }\end{array}$ & 22 & 25.7 \\
\hline & About 5 to $10 y e a r s$ & 19 & 21.8 \\
\hline & & 5 & 6.0 \\
\hline & $\begin{array}{l}\text { More than } 10 \text { years } \\
\text { older }\end{array}$ & 9 & 10.9 \\
\hline & Don't know & & \\
\hline \multirow{6}{*}{$\begin{array}{l}\text { Place of incident happened } \\
(\mathrm{n}=85)\end{array}$} & At victims' home & 14 & 16.8 \\
\hline & Neighbor & 11 & 12.9 \\
\hline & At school & 7 & 6.6 \\
\hline & Hotel & 20 & 23.8 \\
\hline & $\begin{array}{l}\text { On street during the } \\
\text { night }\end{array}$ & 5 & 5.9 \\
\hline & $\begin{array}{l}\text { At the perpetrator's } \\
\text { house, dating }\end{array}$ & 29 & 33.7 \\
\hline \multirow[t]{2}{*}{ Reported the incident $(n=85)$} & Yes & 9 & 10.9 \\
\hline & No & 76 & 89.1 \\
\hline Place to report $(n=9)$ & Family & 2 & 18.2 \\
\hline \multirow{3}{*}{$\begin{array}{l}\text { (The percentage may not add to 100, as multiple } \\
\text { responses are possible) }\end{array}$} & Friends & 6 & 63.6 \\
\hline & Relatives & 2 & 18.2 \\
\hline & $\begin{array}{l}\text { Legal bodies/Police, } \\
\text { Judge }\end{array}$ & 4 & 45.5 \\
\hline
\end{tabular}




\begin{tabular}{|lllc|}
\hline & Health providers & 2 & 27.5 \\
Reasons for not to have & Fear of social stigma & 35 & 46.7 \\
$\begin{array}{l}\text { (The percentage may not add to 100, as multiple } \\
\text { responses are possible) }\end{array}$ & Cultural influence & 23 & 30.0 \\
& $\begin{array}{l}\text { Fear of consequences } \\
\text { from family }\end{array}$ & 45 & 58.9 \\
& $\begin{array}{l}\text { Threat of harm by } \\
\text { perpetrator }\end{array}$ & 31 & 41.1 \\
& Fear of friends & 3.3 \\
Seek health institutions & Yes & 14 & 16.8 \\
for help $(\mathrm{n}=85)$ & No & 71 & 83.2 \\
\hline
\end{tabular}

Table 3: Factors associated with sexual coercion at sexual debut among respondents, Boset district, Oromia Region, June 2019 


\begin{tabular}{|c|c|c|c|c|}
\hline \multirow{2}{*}{ Variables } & \multicolumn{2}{|c|}{$\begin{array}{l}\text { Sexual coercion at } \\
\text { sexual debut }\end{array}$} & \multirow[t]{2}{*}{ COR $(95 \% \mathrm{Cl})$} & \multirow[t]{2}{*}{ AOR $(95 \% \mathrm{Cl})$} \\
\hline & No- $\%$ & Yes-\% & & \\
\hline \multicolumn{5}{|l|}{ Marital status } \\
\hline Never married & 51.4 & 48.6 & 1.00 & 1.00 \\
\hline Married & 73.1 & 26.9 & $0.390(0.214,0.712)^{\star}$ & $0.711(0.222,2.278)$ \\
\hline Others & 27.3 & 2.3 & $2.755(0.932,8.946)$ & $0.825(0.145,4.686)$ \\
\hline \multicolumn{5}{|l|}{$\begin{array}{l}\text { Living arrangements } \\
\text { (Currently live with) }\end{array}$} \\
\hline Both parents & 54.0 & 46.0 & 1.00 & 1.00 \\
\hline Father/Mother only & 53.2 & 46.8 & $1.033(0.465,2.229)$ & $1.265(0.465,3.440)$ \\
\hline Relatives, Fiancé or & 55.6 & 44.4 & $0.939(0.397,2.222)$ & $1.008(0.341,2.978)$ \\
\hline 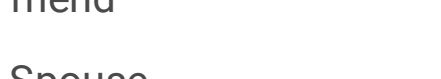 & 77.3 & 22.7 & $0.345(0.155,0.769)^{\star}$ & $0.525(0.109,2.513)$ \\
\hline thonder & 30.0 & 70.0 & $2.739(0.905,8.283)$ & $5.067(1.069,24.011)^{*}$ \\
\hline Housemaid & 21.4 & 78.6 & $4.304(1.069,17.324) \star$ & $3.486(0.494,24.589)$ \\
\hline \multicolumn{5}{|l|}{ Current occupation } \\
\hline Student & 57.6 & 42.4 & 1.00 & 1.00 \\
\hline Housewife & 74.6 & 25.4 & $0.461(0.234,0.910)^{\star}$ & $0.773(0.228,2.620)$ \\
\hline Trade activity & 43.5 & 56.5 & $1.764(0.706,4.408)$ & $1.557(0.384,6.312)$ \\
\hline House maid & 32.1 & 67.9 & $2.865(1.179,6.660)^{\star}$ & $2.400(0.785,7.344)$ \\
\hline Gov. employee /Others & 41.2 & 58.8 & $1.929(0.682,5.512)$ & $2.899(0.825,10.184)$ \\
\hline Age at first sex & & & 1.00 & 1.00 \\
\hline 10- 14 years & 37.0 & 63.0 & $0.397(0.173,0.915)^{\star}$ & $0.186(0.064,0.544)^{*}$ \\
\hline 15- 19 years & 59.7 & 40.3 & $0.294(0.078,1.110)$ & $0.326(0.058,1.826)$ \\
\hline 20- 24 years & 66.7 & 33.3 & & \\
\hline \multicolumn{5}{|l|}{$\begin{array}{l}\text { Consume alcoholic } \\
\text { beverage }\end{array}$} \\
\hline Yes & 43.4 & 56.6 & $2.247(1.287,3.922)^{\star}$ & $2.435(1.167,5.084)^{\star}$ \\
\hline Chew chat & & & 1.00 & \\
\hline
\end{tabular}


${ }^{A}$ djusted for the variables in the table, $* P$-Value $<0.05, * * P$-Value $<0.001$ COR-Crude Odds Ratio, AOR-Adjusted Odds Ratio

Note: variables not entered in the model because they were not found significant in bivariate analysis.

\section{Figures}

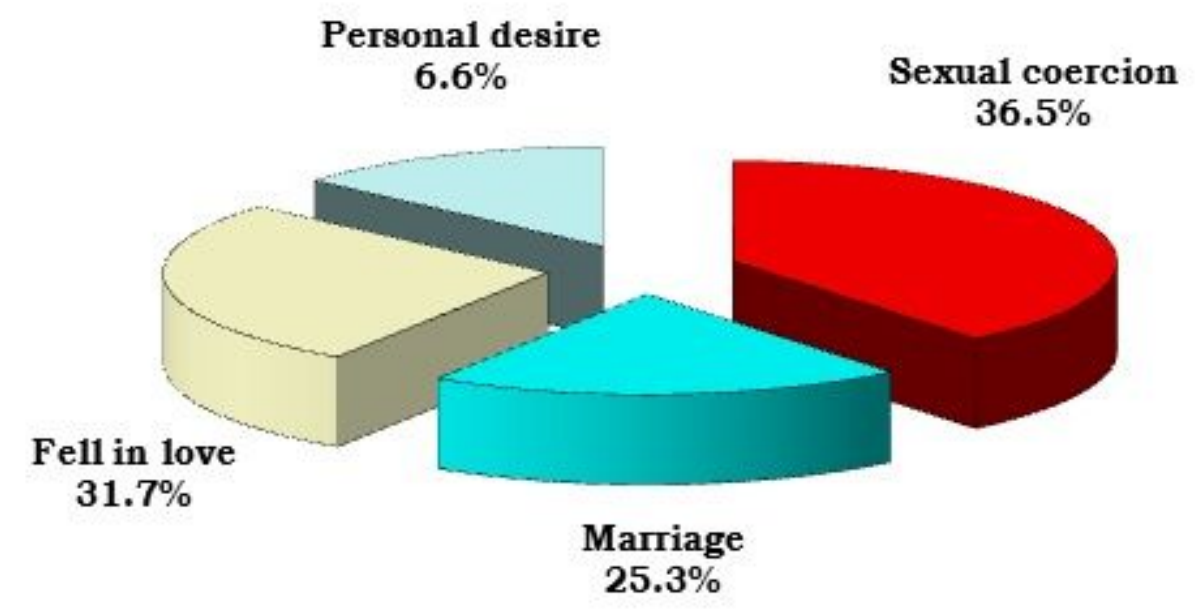

Figure 1

Reasons for sexual commencement of sexually active respondents, Boset district, Oromia Region, June 2019 


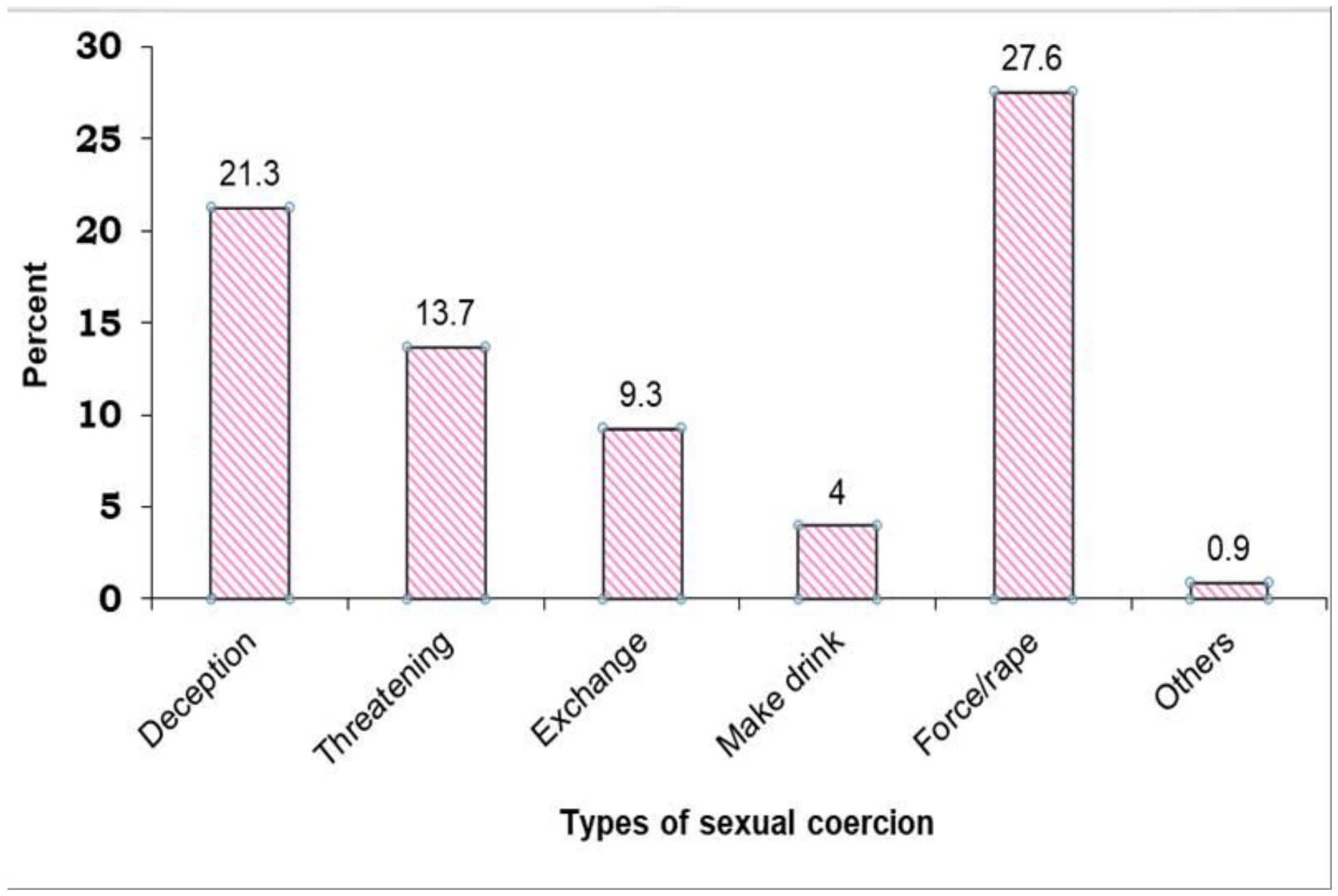

Figure 2

Types of Sexual coercion at the time of sexual debut among sexually active respondents, Boset district, Oromia Region, June 2019

\section{Supplementary Files}

This is a list of supplementary files associated with this preprint. Click to download.

- STROBEchecklistv4combinedPlosMedicine.docx

- Supplementaryfiles.docx 